\title{
Effect of Educational Program on Nurses' Performance Regarding Neonatal Palliative Care
}

\section{Amal Gharib Sabaq}

Lecturer of Pediatric Nursing, Faculty of Nursing, Benha University, Egypt

\section{Samah M. Khalaf}

Lecturer of Pediatric Nursing, Faculty of Nursing, Benha University, Egypt

\begin{abstract}
:
Palliative care is a philosophy of care that provides a combination of disease modifying and supportive, compassionate therapies intended to alleviate pain and other symptoms while addressing the emotional, social, cultural, and spiritual needs of neonates and families who are experiencing life threatening progressive illness. The aim of the current study was to evaluate the effect of educational program on nurses' performance regarding neonatal palliative care. A Quasi-experimental research design was used to conduct the current study at neonatal intensive care units in Benha University Hospital, Teaching Hospital and Specialized pediatric Hospital during the period from December, r. 14 to June, 2015.
\end{abstract} Subjects: A convenient sample of 142 nurses was recruited in this study. Tools: Three tools were utilized for data collection: A Structure Interviewing Questionnaire Sheet, Nurses' Practice Observation Checklist, and Attitude Likert Scale. Results: There were statistically significant differences in nurses' knowledge, practice and attitude regarding neonatal palliative care before and after program implementation. Conclusion: Based on the results of the present study, it can be concluded that, the research hypothesis is accepted while it was found that, the educational program are an effective method to improve the nurses' knowledge, practice, and attitude regarding neonatal palliative care. Recommendation: Continuous refreshing training program should be provided in order to update the nurses' knowledge, improve their level of practice, and develop a positive attitude towards neonatal palliative care. Availability and accessibility of written guidelines in hospitals and units related to neonatal palliative care.

Key Words: Educational program, neonatal palliative care, nurses performance, 


\section{Tanta Scientific Nursing Journal}

\section{Introduction:}

Neonatal palliative care includes the provision of physical, psychological, social, emotional, and spiritual care for both the neonate and the family. It can be provided for neonates from the diagnosis of their life-threatening illness. It is not an alternative method of care, but instead, a method of care that can coexist with curative treatments to provide neonates and families with the best possible treatment. Effective palliative care requires a broad multidisciplinary approach that includes the family and makes use of available community resources; it can be successfully implemented and provided in any care setting ${ }^{(1)}$. It is provided through a team usually made up of nurses, medical doctors, pharmacists, social workers, spiritual leaders, and psychologists who work together to help neonates live as actively as possible until death ${ }^{(2,3)}$.

The aim of palliative care nursing is an effective management of pain and discomfort for neonates who cannot benefit from intensive care and to provide culturally sensitive support for the family (4) Furthermore, the principle of pediatric palliative care should center on a neonate's and family's quality of life. It is important to encourage families to focus on the quality of the neonate's life and not the quantity of days lived ${ }^{(5)}$. Quality of life may be defined differently for each neonate, but by managing distressing symptoms, providers may be able to not only improve the neonate's quality of life, but positively impact the course of the neonate's illness ${ }^{(6)}$.

Principles of neonatal palliative care are emphasis on improved communication and decision making. Communication is central to palliative care, and speaking with the family about their wishes and desires, as well as their definitions of what quality of life means is important ${ }^{(7)}$. Moreover, delivery of effective and caring communication by nurses is essential to provide families with accurate, consistent information about the neonate's diagnosis, and treatment to empower them to make informed decisions about care for their neonate (8). Additionally, when communication is delivered in a clear, honest, and sensitive manner to families can enhance the nurses' satisfaction with the care they provide and also, the parents' satisfaction with the care they receive ${ }^{(9)}$. Open communication can also foster trust between the nurse and the family and facilitate a peaceful death for the neonate ${ }^{(10)}$. 
Globally, the World Health Organization ${ }^{(4)}$ estimated that,1.2 million children worldwide are in need of palliative care at the end of life. The most frequent causes of death by disease groups are congenital anomalies $(25.06 \%)$, followed by neonatal conditions (64.0\%) . Moreover, more than 29,000 infants under 1 year of age die each year in the United States, and $66.0 \%$ of these deaths occur during the neonatal period mainly in the neonatal intensive care unit ${ }^{(11)}$. Every year, more than 500,000 children live with a life-limiting illness and in need of appropriate palliative care. These life-limiting conditions, including severe prematurity and its accompanying complications, birth-related trauma, genetic abnormalities, or complex congenital anomalies, whether the condition will result in death during the infant's first few hours of life or after several years ${ }^{(12,13)}$. In Egypt, the infant mortality rate was 25 deaths per 1000 births, and the neonatal mortality rate was 16 deaths per 1000 births. This indicates that about $87.0 \%$ of early childhood deaths in Egypt are taking place before a child's first birthday, with more than half $(58.0 \%)$ occurring during the first month of life ${ }^{(14)}$. One barrier to timely initiation of palliative care for neonate is the discomfort that some physicians and nurses have with candid discussions about end-of-life care with families. Early consultation with a palliative care team can facilitate this discussion. Another barrier is the uncertain short-term prognosis of many neonates who admitted to the intensive care unit. Nurses also may lack education in palliative care, so they do not understand care options for these neonates. They may try to avoid dying neonates because they lack coping mechanisms ${ }^{(15)}$. By lacking a set protocol with clear criteria for neonates requiring palliative care and lacking education regarding palliative care, nurses are at risk of developing moral distress. However, some of these barriers can be overcome using approaches that enhanced communication, continuity of care, advance care planning, staff training and systematic changes in clinical care practice $^{(16)}$.

Nurses by the nature of their jobs play a major role in the neonatal palliative care team as they are usually in constant touch with neonates and their relatives. They work with other professional groups to advance the body of knowledge about palliative care, initiating and conducting research and incorporating research findings where appropriate ${ }^{(17,18,19)}$. Moreover, The International Council of 


\section{Tanta Scientific Nursing Journal}

Nurses $^{(20)}$ views the nurse's role as fundamental to a palliative approach that aims to reduce suffering and improve the quality of life for dying neonates and their families through early assessment, identification, and management of physical, social, psychological, spiritual, and cultural needs. Educating nurses about communicating palliative needs to families is an important step in establishing achievable goals of care ${ }^{(21)}$.

\section{Significance of the Study:}

There is a clear need for a comprehensive neonatal care strategy to support dying neonates and their families at the earliest possible time frame ${ }^{(22)}$. Palliative care is a model that is consistent with basic nursing values, which include caring for neonates and their families, regardless of their age, culture, socioeconomic status, or diagnoses, and engaging in caring relationships that transcend time, location, and circumstances ${ }^{(23)}$. According to an Institute of Medicine (24) report on the future of nursing, nurses working in intensive care settings are in an optimal position to provide palliative care and meet the growing needs of neonate in intensive care facilities. Furthermore, previous studies founded that, nurses have lacked knowledge and skills in providing palliative care. Also, neonatal nurses have few opportunities for continuing education. The deficit in knowledge, skills, and opportunities for continuing education underscore the need to promote knowledge about evidence-based palliative care practice $^{(25,26,27,28)}$. Hence, the researchers found urgent to conduct an educational program for nurses about the neonatal palliative care to enhance their knowledge, practices, and attitude that could help neonates receive quality comfort care and families receive support through a difficult time.

\section{Aim of the study:}

The aim of this study was to evaluate the effect of educational program on nurses' performance regarding neonatal palliative care through:

- Assessing nurses' knowledge, practice, and attitude related to neonatal palliative care.

- Designing and implementing educational program based on nurses' actual needs about neonatal palliative care

- Evaluating the effect of educational program on nurses' knowledge, practice, and attitude toward neonatal palliative care.

\section{Research Hypotheses:}

- The level of nurses' knowledge about neonatal palliative care will increase significantly after implementation of educational program. 
- The level of nurses' practice about neonatal palliative care was improved significantly after implementation of educational program.

- The level of nurses' attitude towards neonatal palliative care was changed significantly after implementation of educational program.

- There are a significant relationship between nurses' knowledge, practice, and attitude related to neonatal palliative care and their personal characteristics.

\section{Subjects and Method:}

\section{Research Design:}

A quasi experimental design was used to conduct this study.

\section{Settings:}

The study was carried out at neonatal intensive care units in Benha University Hospital, Teaching Hospital, and Specialized Pediatric Hospital in Benha City.

\section{Sample:}

Convenient sample of 142 nurses who are working at the previously mentioned settings were taken according to inclusion criteria that included the following:-

- Responsible for direct neonatal care.

- Both male and female.

- Years of experience not less than one years.

\section{Tools of Data Collection:}

\section{Tool (I): A Structured Interviewing} Questionnaire Sheet:

It was developed by the researcher based on the scientific literature of Kassa etal., (2014) ; South Central Palliative Care Group, (2012) ${ }^{(29,30)}$. It was translated to Arabic language to assess the nurses' knowledge regarding neonatal palliative care. It comprised two main parts which are:

Part I : Personal characteristic of the studied nurses as; age, gender , qualifications, years of experience, number of dying neonate had you cared for, and previous attendance of training programs about neonatal palliative care.

Part II : Nurses' knowledge about palliative care. It consisted of 13 true / false and multiple choice questions covering the questions related to (definition, benefits, principles, philosophy of palliative care, palliative care is appropriate only in deterioration condition, the extent of disease determines the method of pain treatment, Provision of palliative care require emotional detachment, and role of palliative care nurse.

The scoring system consisted of giving a score of one for the correct answers and zero for the wrong answers. Score of 
$80.0 \%$ and more was considered good level of knowledge, $60.0 \%$ to less than $80.0 \%$ was considered moderate knowledge, while a score below $60.0 \%$ was considered poor knowledge.

Tool (II): Attitude Likert Scale which adopted from Frommelt, (2003) ${ }^{(31)}$ and modified by the researchers to suit the current study : It contains 20 items tool using a three-point likert scale to indicate nurses' attitudes toward neonatal palliative care. The scale consists of an equal number of positively and negatively worded statements with response options of strongly disagree, uncertain, and agree. Positive items are scored one (strongly disagree) to three (agree). Scores are reversed for negative items. Total scores was range from 20-60. The researchers were considered attitude scores less than $60.0 \%$ negative attitude, while $60.0 \%$ and more, positive attitude.

Tool (III) : Nurses' Practice Observation Checklist: It was adopted from Mancini etal., (2014) $)^{(13)}$ and modified by the researchers to suit the Egyptian culture. It was designed to assess nurses' practices regarding neonatal palliative care. It included 37 procedures grouped under 8 main domain named discussion with parents about palliative care (5 items), pain relief (6 items), comfort care measures (5 items), symptoms control (3 items), physiological monitoring (5 items), nutrition (5 items), ventilation \& oxygen therapy (4 items), and family support(4 items).

The scoring system consisted of two points: give a score of one for done and a score of zero for not had done. Scores of less than $80.0 \%$ were considered incompetent practice, while a score greater than or equal to $80.0 \%$ were considered competent practices.

\section{Validity and Reliability of the Tool:}

Data collection tools were submitted to five experts of Pediatric Nursing field from the Faculty of Nursing, Ain Shams, El-Menofia, and Zagazig Universities, to test the content validity. Modifications of the tools were done according to the expert's judgment on clarity of sentences, appropriateness of content and sequence of items. The experts' agreed on the content, but recommended minor language changes that would make the information clearer and more precise. The suggested changes were made. Internal consistency reliability of all items of the tools was assessed using coefficient alpha. It was 0.83 for Structured Interviewed Questionnaires Sheet, 0.86 for Nurses Practices Observation Checklist, and 0.79 for the Attitude Likert Scale. 


\section{Educational Program:}

The educational program was developed by the researchers based on assessment phase and after reviewing the related literature.

\section{Preparatory Phase:}

A review of the past and current available literature in various aspects of the problem using books, articles, periodicals, and magazines was done to be acquainted with all aspects of the study problem and also in order to develop relevant tools for data collection and the content of the program.

\section{Pilot Study:}

The pilot study was carried out on $10.0 \%$ of the study subject (14 nurses) over a period of one month (November, 2014). The purpose was to ascertain the feasibility of the study and the clarity and applicability of the tools. It also helped to estimate the time needed for filling out the forms. Based on the results of the pilot, no modifications were needed and pilot study subjects were excluded from the sample of the study.

\section{Ethical Considerations:}

The present study was conducted under the approval of the Faculty of Nursing Ethical Committee, Benha University. Then approval was obtained from the hospital manager and head of intensive care units in the previously mentioned study settings through submission of an official letters issued from the dean of Faculty of Nursing, Benha University. Participants were given explanation about the purpose of the study, and they were also informed that they could withdraw from the study at any time without giving any reason. An informed signed consent was obtained from each nurse in the study. Confidentiality of participants' information was assured and the data were accessed only by the researchers involved in the study.

\section{Field Work:}

\section{a) Assessment Phase}

The actual field work was carried out from the beginning of December, $r \cdot 14$ to the end of June, 2015. A permission to conduct the study was obtained from the directors of previous mentioned settings and acceptance from nurses to participate in the study. In the beginning, the researchers introduced themselves to the nurses and give them a brief idea about the study and its purpose. Then, each nurse was interviewed for about 10 to 20 minutes to fill out the knowledge questionnaire sheet about neonatal palliative care ( Tool 1) and attitude likert scale ( Tool 2) by rotation five days per week at morning and afternoon shifts. Also, each nurse was observed during 
demonstrating neonatal palliative care on two different shifts using observation checklist (Tool 3). The time required for each observation was ranged 10 to 15 minutes.

\section{b) Program Construction:}

The educational program for nurses was designed by the researchers according to the nurses' needs regarding neonatal palliative care. It was constructed, revised, and modified from the related literature to improve the nurses' knowledge, practices, and attitude regarding neonatal palliative care. The contents were prepared in simple Arabic language to be easy understood for the nurses.

\section{c) Statement of Objectives:}

The general objective of the program was to improve nurses' knowledge, practice, and attitude regarding neonatal palliative care.

\section{d) Program Implementation:}

The program was carried out at the study settings through 13 sessions ( 5 sessions for theory and 8 sessions for practice). A time schedule suitable for nurses was developed to conduct the program that included; date, place, topic, time, and duration of each session. The training program consisted of two parts, the theoretical part cover (definition of palliative care, benefits, , principles, reasons, philosophy, and role of nurse regarding palliative care......ect) and the practical parts cover the nursing role related to control of pain, comfort measures, symptom management, ventilation therapy, oxygen therapy, nutrition, and support of family). These sessions have lasted for 21 hours. It was difficult to take all nurses at the same time. Thus, they were divided into 28 groups of about 5 nurses in every session and a copy of the education/training program contents was given to each nurse. Nurses participated in the educational program activities for one hours of theoretical and 2 hours of practical, the program started from 9 to $10 \mathrm{AM}$ for theory sessions \& 10.30 $\mathrm{AM}$ to $12.30 \mathrm{PM}$ for practical sessions five days/week. The researchers started each session with a summary for the previous one. Methods of teaching were lectures, brain storming, group discussion, demonstration and redemonstration. Proper audio-visual materials such as data show were used in order to help proper understanding of contents by nurses.

\section{e) Evaluation:}

After the completion of the program contents, the post test similar to the pretest and practical demonstration were done to the nurses for measuring their 
knowledge, practice, and attitude regarding neonatal palliative care.

\section{Statistical Analysis:}

Data analysis was performed using IBM SPSS statistical software version 20. The data were explored. Descriptive statistics with mean and standard deviation (SD) for continuous variables and frequency for categorical variables were analyzed. Qualitative variables were compared using Chi square test $\left(X^{2}\right)$ as the test of significance was used to evaluate changes in the pre- intervention and postintervention program implementation. Pearson correlation coefficient was used to compare between variables and personal characteristics date. The p-value is the degree of significant. A significant level value was considered when $p$-value $\leq 0.05$ and a highly significant level value was considered when $\mathrm{p}$-value $\leq 0.001$, while $\mathrm{p}$ value $>0.05$ indicates non-significant results.

\section{Limitation of the Study:}

1- Some of the nurses were too overloaded with work. So, they preferred discontinuation in the study.

2- The use of a convenience sample restricts the generalizability beyond the population from which the data were drawn.

\section{Results:}

Table (1) : clarifies that, the mean age of the studied nurses was $(24.97 \pm 4.807)$ years. The majority of them were female and working at specialized pediatric hospital $(91.5 \%$, \& 69.7\%) respectively. In relation to nurses' education, $77.10 \%$ of them had diploma in nursing, while $10.5 \%$ of them had Bachelor degree in nursing and the remaining (5.20\%) of nurses graduated from Technical Institute of Nursing. Also, it was noticed that, two thirds of nurses $(62 \%)$ had years of experiences ranged from 5 to less than 10 years, and $49.3 \%$ of them cared more than 10 children who have died, while $73.9 \%$ of them not attendance of previous training regarding neonatal palliative care.

Table(2): shows nurses' knowledge regarding neonatal palliative care throughout the program phases. It was found that, high percentage of them $(97.1 \%$ ,96.5\%, $96.5 \%, \quad 95.8 \% \quad \& \quad 94.4 \%$ ) respectively had correct answers after the program implementation compared with their scores before program in the items related to definition of palliative care, benefits of palliative care that provides relief from pain and offers a support system to help the family cope during the neonates' illness, principles of palliative 
care, and role of neonatal palliative care nurse. There was a highly statistically significant difference $(\mathrm{p}=<0.001)$.

Table (3): shows nurses' attitude regarding neonatal palliative care throughout the program phases. It was illustrated that, before implementation of the program, the majority $72.5 \%$ of the studied nurses agreed with statement related to palliative care is given only for dying patient while after implementation of the program $93.0 \%$ of them disagreed. Moreover, the highest percentage of nurses $(92.3 \%, 91.5 \%$, $90.8 \%$ \& 90.8\%) respectively agreed with statements related to family should involved in the physical care of dying babies, nursing care for family should continue throughout grief and bereavement, it is possible for nurse to help neonate prepare for death and families should be in charge of decision making after program implementation. There was a highly statistical significant improvement in all items of nurses attitude after program implementation $(\mathrm{p}=<0.001)$.

Table (4): Shows nurses' practices about discussion with parent, pain relief and comfort measures throughout the program phases. It was noticed that, only $6.3 \%$ the studied nurses who provide the parents with information about their neonate diagnosis and prognosis pre program implementation compared to $63.4 \%$ postprogram implementation. In relation to pain control, $14.1 \%$ of the studied nurses continue to provide analgesic to control pain and distress and none of them make assessment to identify neonate pain and distress pre program compared to $95.8 \%$ \& $94.4 \%$ post- program implementation respectively. Meanwhile, it is clear from this table that, before program implementation only $16.9 \%$ of nurses ensuring the nappy is clean, dry, and $12.0 \%$ of them cuddling and holding the neonate compared to post program implementation $(100.0 \%, \& 100.0 \%)$ respectively. These difference were statistically significant whereas $(\mathrm{P}<0.05$, $\mathrm{P}<0.05, \& \mathrm{P}<0.001)$ respectively.

Table 5: presents nurses' practices about symptoms control, physiological monitoring and nutrition throughout the program phases. In relation to symptoms control, it was noticed that, $7.0 \% \& 3.5 \%$ of the studied nurses who gave anticonvulsants drug to control seizures and performed gentle suctioning to decrease respiratory and salivary secretion pre program implementation compared to post- program implementation (97.2 \& $95.1 \%$ ) respectively . In relation to physiological monitoring, only $2.8 \%$ and $4.2 \%$ of the studied nurses who discontinue invasive technique as blood 
pressure measuring and monitor the physical signs that suggest discomfort such as crying, tachycardia and excessive secretion pre program compared to post program implementation $(97.2 \%$ \& $90.1 \%$ ) respectively. Meanwhile, it is clear from this table that, before program implementation only $4.2 \%$ of nurses' continuous provision of hydration and nutrition and none of them were reduce volume of enteral feeds in case of vomiting compared to post- program implementation $\quad(95.8 \%, \quad \& \quad 95.1 \%)$ respectively. These differences were statistically significant $(\mathrm{P}<0.001)$.

Table 6: shows nurses' practices about ventilation \& oxygen therapy and family support throughout the program phases. It was noticed that, $7 . r \%, \& v^{\circ} . \%$ of the studied nurses turn off the alarms of the ventilator prior to disconnecting and continuous provision of supplemental oxygen to provide comfort to neonates pre program implementation compared to post program implementation $\quad(93.0 \% \quad \&$ $93.7 \%$ ) respectively. In relation to family support, only $16.6 \% \& 12.7 \%$ of the studied nurses who provides reassurance to parents and support to overcome their grief and encourage parents to spend more time with their neonate pre program compared to post program implementation ( $87.3 \%$ \& $83.1 \%$ ) respectively. These difference were statistically significant (P $<0.001)$.

Table (7): Shows the total knowledge and practices scores of nurses regarding neonatal palliative care throughout the program phases. It is clear from this table that, before implementation of the program, the majority $(88 \%, 95.8 \%, \&$ $97.2 \%$ ) of nurses have poor knowledge, incompetent practice and negative attitude regarding neonatal palliative care respectively. After implementation of the program, the highest percentage of nurses (98.6\%, 92.3\%, \& 97.9\% ) have good knowledge, competent practice and positive attitude respectively.

Table (8): Presents correlation between nurses' knowledge, practices, and attitude related to neonatal palliative care and their personal characteristics after program implementation. This table demonstrates positive statistically significant correlation between knowledge and practice scores of the staff nurses $(r=0.657, p=.001)$. Further analysis revealed that, there is a positive correlation between knowledge and attitude with years of experience ( $r=$ $0.689, \mathrm{p}=.001$ and $\mathrm{r}=0.266, \mathrm{p}=.001$ respectively). The table also demonstrates a statistically significant correlation between nurses' knowledge and attitude scores $(r=0.518, p=.001)$. 


\section{Tanta Scientific Nursing Journal}

Table(1): Personal characteristic of the Studied Nurses $($ no= 142)

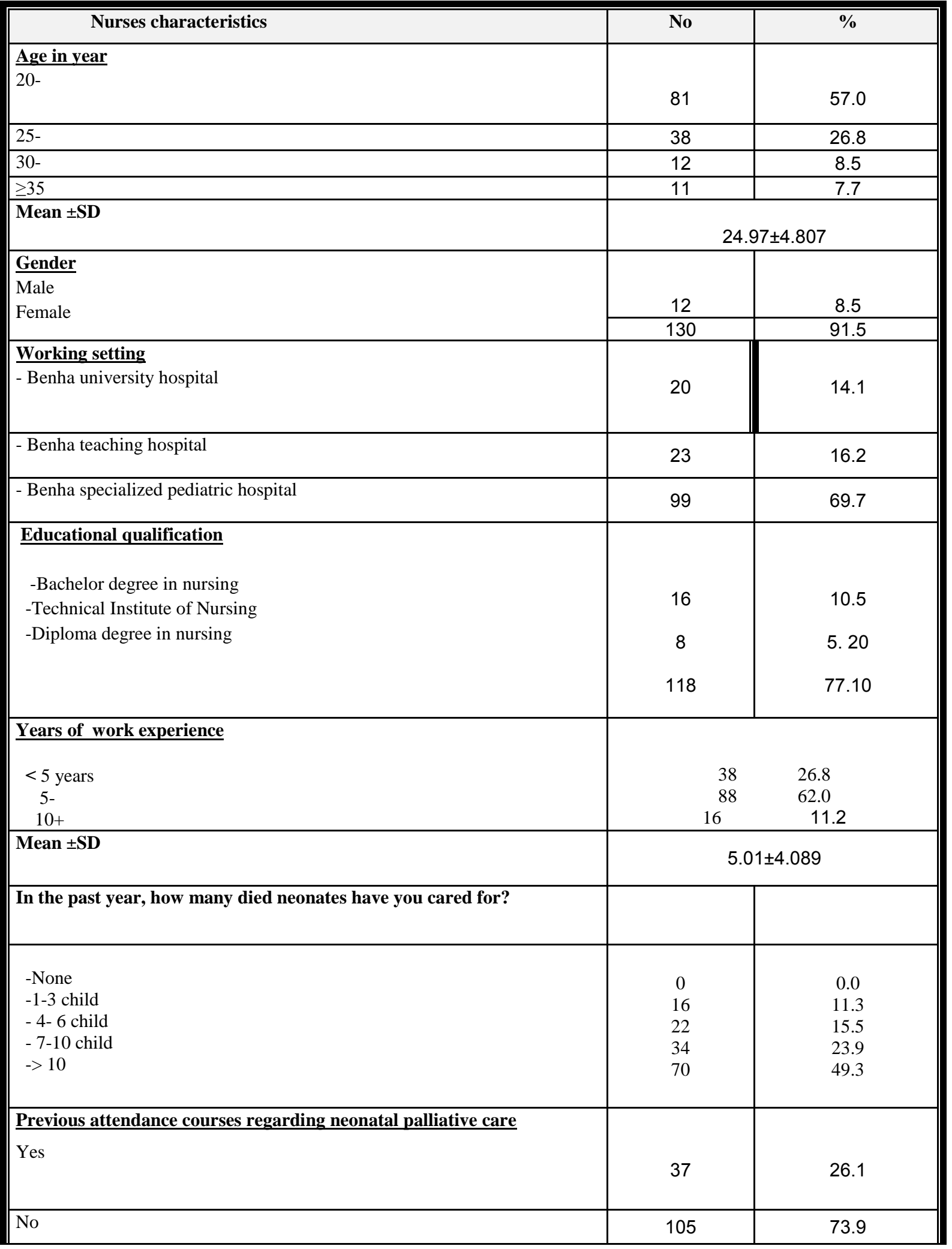


Table (2): Distribution of Nurses Knowledge Regarding Neonatal Palliative Care Throughout the Program Phases( no=142)

\begin{tabular}{|c|c|c|c|c|c|c|c|c|c|c|}
\hline & \multicolumn{4}{|c|}{$\begin{array}{l}\text { Pre program } \\
\text { implementation }\end{array}$} & \multicolumn{4}{|c|}{$\begin{array}{l}\text { Post program } \\
\text { implementation }\end{array}$} & \multirow{3}{*}{$\begin{array}{l}\text { Chi } \\
\text { square } \\
\text { test }\end{array}$} & \multirow[t]{3}{*}{ P value } \\
\hline & \multicolumn{2}{|c|}{ Incorrect } & \multicolumn{2}{|c|}{ Correct } & \multicolumn{2}{|c|}{ Incorrect } & \multicolumn{2}{|c|}{ Correct } & & \\
\hline & No & $\%$ & No & $\%$ & No & $\%$ & No & $\%$ & & \\
\hline $\begin{array}{l}\text { 1- Definition of } \\
\text { neonatal palliative } \\
\text { care }\end{array}$ & 109 & 76.8 & 33 & 23.2 & 0 & .0 & 138 & 97.1 & 178.94 & $\begin{array}{c}<0.001^{*} \\
*\end{array}$ \\
\hline $\begin{array}{l}\text { 2- Palliative care } \\
\text { provides relief from } \\
\text { pain \& other } \\
\text { distressing symptoms }\end{array}$ & 134 & 94.4 & 8 & 5.6 & 6 & 4.2 & 137 & 96.5 & 227.18 & $\begin{array}{c}<0.001 * \\
*\end{array}$ \\
\hline $\begin{array}{l}\text { 3- Palliative care } \\
\text { offers a support } \\
\text { system to help the } \\
\text { family cope during } \\
\text { the neonates' illness }\end{array}$ & 105 & 73.9 & 37 & 26.1 & 0 & .0 & 137 & 96.5 & 145.02 & $\begin{array}{c}<0.001 * \\
*\end{array}$ \\
\hline $\begin{array}{l}\text { 4- Provision of palliative } \\
\text { care require emotional } \\
\text { detachment }\end{array}$ & 126 & 88.7 & 16 & 11.3 & 11 & 7.7 & 131 & 92.3 & 186.49 & $\begin{array}{c}<0.001^{*} \\
*\end{array}$ \\
\hline $\begin{array}{l}\text { 5- The philosophy of } \\
\text { palliative care is } \\
\text { compatible with that of } \\
\text { aggressive treatment. }\end{array}$ & 113 & 79.6 & 28 & 19.7 & 30 & 21.1 & 112 & 78.9 & 113.12 & $\begin{array}{c}<0.001 * \\
*\end{array}$ \\
\hline $\begin{array}{lr}6-\text { Principles of palliative } \\
\text { care based on symptom } \\
\text { management, improved } \\
\text { communication } \\
\text { decision making } & \text {, and } \\
\end{array}$ & 107 & 75.4 & 35 & 24.6 & 0 & .0 & 136 & 95.8 & 153.38 & $\begin{array}{c}<0.001 * \\
*\end{array}$ \\
\hline $\begin{array}{lcc}\text { 7-Palliative } & \text { care } & \text { is } \\
\text { appropriate } & \text { only } & \text { in } \\
\text { deterioration condition } & \end{array}$ & 103 & 72.5 & 39 & 27.5 & 12 & 8.5 & 130 & 91.5 & 90.95 & $\begin{array}{c}<0.001 * \\
*\end{array}$ \\
\hline $\begin{array}{l}8-\text { Palliative care is a } \\
\text { human right. }\end{array}$ & 142 & 100.0 & 0 & .0 & 10 & 7.0 & 132 & 93.0 & 264.68 & $\begin{array}{c}<0.001 * \\
*\end{array}$ \\
\hline $\begin{array}{l}\text { 9- Palliative care should } \\
\text { in no way become a } \\
\text { substitute for appropriate } \\
\text { curative care }\end{array}$ & 111 & 78.2 & 31 & 21.8 & 29 & 20.4 & 113 & 93.7 & 78.89 & $\begin{array}{c}<0.001 * \\
*\end{array}$ \\
\hline $\begin{array}{l}\text { 10- palliative care should } \\
\text { be delivered on the basis } \\
\text { of need, not diagnosis or } \\
\text { prognosis }\end{array}$ & 113 & 79.6 & 28 & 19.7 & 30 & 21.1 & 112 & 78.9 & 113.12 & $\begin{array}{c}<0.001 * \\
*\end{array}$ \\
\hline $\begin{array}{l}\text { 11- The extent of disease } \\
\text { determines the method of } \\
\text { pain treatment }\end{array}$ & 108 & 76.1 & 34 & 23.9 & 9 & 6.3 & 133 & 93.7 & 142.45 & $\begin{array}{c}<0.001 * \\
*\end{array}$ \\
\hline $\begin{array}{l}\text { 12- palliative care should } \\
\text { be provided even when } \\
\text { curative } \\
\text { unavailable }\end{array}$ & 136 & 95.8 & 6 & 4.2 & 30 & 21.1 & 112 & 78.9 & 227.27 & $\begin{array}{c}<0.001 * \\
*\end{array}$ \\
\hline $\begin{array}{l}\text { 13- Role of neonatal } \\
\text { Palliative care nurse }\end{array}$ & 135 & 95.1 & 7 & 4.9 & 7 & 5.0 & 134 & 94.4 & 220.16 & $\begin{array}{c}<0.001^{*} \\
*\end{array}$ \\
\hline
\end{tabular}


Table (3): Distribution of Nurses Attitude Regarding Neonatal Palliative Care throughout the Program Phases( no=142)

\begin{tabular}{|c|c|c|c|c|c|c|c|c|c|c|c|c|c|c|}
\hline & \multicolumn{6}{|c|}{ Pre program implementation } & \multicolumn{6}{|c|}{ Post program implementation } & \multirow{3}{*}{$\begin{array}{l}\text { Chi } \\
\text { square } \\
\text { test }\end{array}$} & \multirow{3}{*}{$\begin{array}{c}\mathbf{P} \\
\text { value }\end{array}$} \\
\hline & \multicolumn{2}{|c|}{ Disagree } & \multicolumn{2}{|c|}{ Uncertain } & \multicolumn{2}{|c|}{ Agree } & \multicolumn{2}{|c|}{ Disagree } & \multicolumn{2}{|c|}{ Uncertain } & \multicolumn{2}{|c|}{ Agree } & & \\
\hline & $\begin{array}{l}\mathbf{N} \\
\mathbf{0}\end{array}$ & $\%$ & No & $\%$ & No & $\%$ & No & $\%$ & No & $\%$ & No & $\%$ & & \\
\hline $\begin{array}{l}\text { 1- palliative care is given } \\
\text { only for dying patient }\end{array}$ & 13 & 9.2 & 26 & 18.3 & 103 & 72.5 & 132 & 93.0 & 1 & 0.7 & 9 & 6.3 & 111.59 & $\begin{array}{r}<0.00 \\
1 * *\end{array}$ \\
\hline $\begin{array}{l}\text { 2-Nursing care for the } \\
\text { family should continue } \\
\text { throughout the } \\
\text { period of grief and } \\
\text { bereavement. }\end{array}$ & $\begin{array}{l}14 \\
0\end{array}$ & $\begin{array}{l}98 . \\
6\end{array}$ & $\mathbf{0}$ & .0 & 2 & 1.4 & 5 & 3.5 & 7 & 4.9 & 130 & $\begin{array}{l}91 . \\
5\end{array}$ & 213.37 & $\begin{array}{r}<0.00 \\
1 * *\end{array}$ \\
\hline $\begin{array}{l}\text { 3- I would not want to care } \\
\text { for a dying neonate. }\end{array}$ & 42 & $\begin{array}{l}29 . \\
6\end{array}$ & 50 & 35.2 & $\mathbf{5 0}$ & 35.2 & 116 & 81.7 & 8 & 5.6 & 18 & $\begin{array}{l}12 . \\
7\end{array}$ & 109.54 & $\begin{array}{r}<0.00 \\
1 * * \\
\end{array}$ \\
\hline $\begin{array}{l}\text { 4- Length of time required } \\
\text { to give nursing care to a } \\
\text { dying neonate would } \\
\text { frustrate me. }\end{array}$ & 4 & 2.8 & 20 & 14.1 & 118 & 83.1 & 79 & 55.6 & 17 & $\begin{array}{l}12 . \\
0\end{array}$ & 46 & $\begin{array}{l}32 . \\
4\end{array}$ & 146.00 & $\begin{array}{r}<0.00 \\
1 * *\end{array}$ \\
\hline $\begin{array}{l}\text { 5- It is difficult to form a } \\
\text { close relationship with dying } \\
\text { neonate. }\end{array}$ & 20 & 14. & 8 & 5.6 & 114 & 80.3 & 111 & 78.2 & 16 & 11. & 15 & $\begin{array}{l}10 . \\
6\end{array}$ & 145.85 & $\begin{array}{r}<0.00 \\
1 * *\end{array}$ \\
\hline $\begin{array}{l}\text { 6-- Families should maintain } \\
\text { as normal an environment } \\
\text { as possible for their dying } \\
\text { neonate }\end{array}$ & 70 & $\begin{array}{l}49 . \\
3\end{array}$ & 43 & 30.3 & 29 & 20.4 & 11 & 7.7 & 7 & 4.9 & 124 & $\begin{array}{l}87 . \\
3\end{array}$ & 127.88 & $\begin{array}{r}<0.00 \\
1 * *\end{array}$ \\
\hline $\begin{array}{l}\text { 7- The family should be } \\
\text { involved in the physical care } \\
\text { of the dying neonate }\end{array}$ & 95 & $\begin{array}{l}52 . \\
8\end{array}$ & 45 & 31.7 & 2 & 1.4 & 9 & 6.3 & 2 & 1.4 & 131 & $\begin{array}{l}92 . \\
3\end{array}$ & 146.25 & $\begin{array}{r}<0.00 \\
1 * *\end{array}$ \\
\hline $\begin{array}{lrrr}\begin{array}{l}\text { 8-I am } \\
\text { friends } \\
\text { neonate. }\end{array} & \text { with } & \text { a } & \text { dying } \\
\text { neocome } \\
\end{array}$ & 12 & 8.5 & 0 & .0 & 130 & 91.5 & 123 & 86.6 & 18 & 12. & 1 & .7 & 177.02 & $\begin{array}{r}<0.00 \\
1 * *\end{array}$ \\
\hline $\begin{array}{l}\text { 9- I would feel like running } \\
\text { away when the neonate } \\
\text { actually died. }\end{array}$ & 29 & 20. & .0 & .0 & 113 & 79.6 & 112 & 78.9 & 19 & $\begin{array}{l}13 . \\
4\end{array}$ & 11 & 7.7 & 184.92 & $\begin{array}{r}<0.00 \\
1 * *\end{array}$ \\
\hline $\begin{array}{l}\text { 10- Families need emotional } \\
\text { support to accept behavior } \\
\text { changes of dying neonate. }\end{array}$ & 97 & $\begin{array}{l}68 . \\
3\end{array}$ & 24 & 16.9 & 21 & 14.8 & 21 & 14.8 & 10 & 7.0 & 111 & $\begin{array}{l}78 . \\
2\end{array}$ & 116.07 & $\begin{array}{r}<0.00 \\
1 * *\end{array}$ \\
\hline $\begin{array}{l}\text { 11-As a patient nears death, } \\
\text { the nurse should withdraw } \\
\text { from his/her involvement } \\
\text { with the patient. }\end{array}$ & 11 & 7.7 & 51 & 35.9 & 80 & 56.3 & 109 & 76.8 & 8 & 5.6 & 25 & $\begin{array}{l}17 . \\
6\end{array}$ & 89.20 & $\begin{array}{r}<0.00 \\
1 * *\end{array}$ \\
\hline $\begin{array}{l}\text { 12- Families should be } \\
\text { concerned about helping } \\
\text { their dying neonate make } \\
\text { the best of his remaining life. }\end{array}$ & 11 & $\begin{array}{l}78 . \\
2\end{array}$ & $\mathbf{0}$ & .0 & 31 & 21. & 20 & 14.1 & 9 & 6.3 & 113 & $\begin{array}{l}79 . \\
6\end{array}$ & 118.90 & $\begin{array}{r}<0.00 \\
1 * *\end{array}$ \\
\hline $\begin{array}{l}\text { 13- The families should not } \\
\text { be allowed to make decisions } \\
\text { about his neonate physical } \\
\text { care. }\end{array}$ & 29 & $\begin{array}{l}20 . \\
4\end{array}$ & 1 & .7 & 112 & 78.9 & 113 & 79.6 & 13 & 9.2 & 16 & 11. & 131.97 & $\begin{array}{r}<0.00 \\
1 * *\end{array}$ \\
\hline $\begin{array}{l}\text { 14. It is possible for nurse to } \\
\text { help neonate prepare for } \\
\text { death }\end{array}$ & $\begin{array}{l}11 \\
3\end{array}$ & $\begin{array}{l}79 . \\
6\end{array}$ & 8 & 5.6 & 21 & 14.8 & 4 & 2.8 & 9 & 6.3 & 129 & $\begin{array}{l}90 . \\
8\end{array}$ & 174.15 & $\begin{array}{r}<0.00 \\
1 * *\end{array}$ \\
\hline $\begin{array}{l}\text { 15-Addiction to pain } \\
\text { relieving medication should } \\
\text { be a concern when dealing } \\
\text { with a dying neonate. }\end{array}$ & 11 & 7.7 & $\mathbf{1 0}$ & 72.5 & 28 & 19.7 & 7 & 4.9 & 11 & 7.7 & 124 & $\begin{array}{l}87 . \\
3\end{array}$ & 122.35 & $\begin{array}{r}<0.00 \\
1 * *\end{array}$ \\
\hline $\begin{array}{l}\text { 16- When a family ask nurse } \\
\text { "Am" my neonate dying? I } \\
\text { think it is best to change the } \\
\text { subject to a something } \\
\text { cheerful. }\end{array}$ & 88 & $\begin{array}{l}62 . \\
0\end{array}$ & 27 & 19.0 & 27 & 19.0 & 55 & 38.7 & 11 & 7.7 & 76 & $\begin{array}{l}53 . \\
5\end{array}$ & 102.25 & $\begin{array}{r}<0.00 \\
1 * *\end{array}$ \\
\hline $\begin{array}{l}\text { 17-Families should be in } \\
\text { charge of decision making. }\end{array}$ & 14 & 9.9 & 97 & 68.3 & 31 & 21.8 & 1 & 0.7 & 12 & 8.5 & 129 & $\begin{array}{l}90 . \\
8\end{array}$ & 113.52 & $\begin{array}{r}<0.00 \\
1 * *\end{array}$ \\
\hline $\begin{array}{l}\text { 18- Families should be given } \\
\text { honest answers about their } \\
\text { neonate condition. }\end{array}$ & $\begin{array}{l}12 \\
8\end{array}$ & $\begin{array}{l}90 . \\
1\end{array}$ & 5 & 3.5 & 9 & 6.3 & 8 & 5.6 & 27 & $\begin{array}{l}19 . \\
0\end{array}$ & 107 & $\begin{array}{l}75 . \\
4\end{array}$ & 203.80 & $\begin{array}{r}<0.00 \\
1 * *\end{array}$ \\
\hline $\begin{array}{l}\text { 19-Educating families about } \\
\text { death and dying is not a } \\
\text { non-family } \\
\text { responsibility. }\end{array}$ & 59 & $\begin{array}{l}41 . \\
5\end{array}$ & 20 & 14.1 & 63 & 44.4 & 99 & 69.7 & 34 & $\begin{array}{l}23 . \\
9\end{array}$ & 9 & 6.3 & 90.44 & $\begin{array}{r}<0.00 \\
1 * *\end{array}$ \\
\hline $\begin{array}{l}\text { 20-Family members who } \\
\text { stay close to a dying neonate } \\
\text { often interfere with the } \\
\text { professionals 'job with the } \\
\text { patient. }\end{array}$ & 4 & 2.8 & 20 & 14.1 & 118 & 83.1 & 111 & 78.2 & 17 & $\begin{array}{l}12 . \\
0\end{array}$ & 14 & 9.9 & 146.00 & $\begin{array}{r}<0.00 \\
1 * *\end{array}$ \\
\hline
\end{tabular}


Table 4: Distribution of Nurses' Practices about Discussion with Parent, Pain Relief and Comfort Measures throughout the Program Phases (n=142)

\begin{tabular}{|c|c|c|c|c|c|c|}
\hline \multirow{3}{*}{ Nurses practices } & \multicolumn{4}{|c|}{$\begin{array}{c}\text { Correct practices } \\
(\mathbf{n}=\mathbf{1 4 2})\end{array}$} & \multirow{3}{*}{$\begin{array}{c}X^{2} \\
\text { P-value }\end{array}$} & \multirow{3}{*}{$P$ value } \\
\hline & \multicolumn{2}{|c|}{ Pre } & \multicolumn{2}{|c|}{ Post } & & \\
\hline & No & $\%$ & No & $\%$ & & \\
\hline $\begin{array}{l}\text { A- Discussions with parents about } \\
\text { neonate's palliative care: }\end{array}$ & & & & & & \\
\hline $\begin{array}{l}\text { 1-- Give information in simple language } \\
\text { about what is wrong with their baby. }\end{array}$ & 4 & 2.8 & 70 & 49.3 & 189.66 & $<0.001^{* *}$ \\
\hline $\begin{array}{l}2 \text { - To be told about the diagnosis and } \\
\text { prognosis of the neonate condition. }\end{array}$ & 9 & 6.3 & 90 & 63.4 & 9.29 & $<0.05^{\star}$ \\
\hline $\begin{array}{l}3 \text { - To be part of the decision making } \\
\text { process }\end{array}$ & 8 & 5.6 & 65 & 45.8 & 156.08 & $<0.001^{* *}$ \\
\hline $\begin{array}{l}4 \text { - Arrange with the family the time and } \\
\text { location for life sustaining treatment }\end{array}$ & 0 & .0 & 50 & 35.2 & 210.67 & $<0.001^{* *}$ \\
\hline 5- Provide written information & 0 & .0 & 80 & 56.3 & 1.06 & $>0.05$ \\
\hline B -Pain relief: & & & & & & \\
\hline $\begin{array}{l}\text { 1- Make frequent assessments to identify } \\
\text { infant pain, distress }\end{array}$ & 0 & .0 & 134 & 94.4 & 8,23 & $<0.05^{*}$ \\
\hline $\begin{array}{l}\text { 2- Discontinue of painful assessments as } \\
\text { heel sticks }\end{array}$ & 0 & .0 & 130 & 91.5 & 12.52 & $<0.001^{* *}$ \\
\hline 3- Leave intravenous access in place & 0 & .0 & 133 & 93.7 & 250.14 & $<0.001^{* *}$ \\
\hline $\begin{array}{l}\text { 4- Continue provision of analgesics to } \\
\text { relief pain and distress }\end{array}$ & 20 & 14.1 & 137 & 95.8 & 121.30 & $<0.001^{* *}$ \\
\hline $\begin{array}{l}\text { 5- Positioning with arms and legs flexed } \\
\text { close to the trunk using blanket or rolls }\end{array}$ & 12 & 8.5 & 111 & 78.2 & 12.52 & $<0.001^{* *}$ \\
\hline $\begin{array}{l}\text { 6- Use non pharmacological intervention } \\
\text { like massage \& distraction technique to } \\
\text { alleviate pain }\end{array}$ & 0 & .0 & 96 & 67.6 & 284.00 & $<0.001^{* *}$ \\
\hline C- comfort measures: & & & & & & \\
\hline $\begin{array}{l}\text { 1. Provide calm environment with minimal } \\
\text { noise and light }\end{array}$ & 4 & Ү.8 & 138 & 97.2 & 83.43 & $<0.001^{* *}$ \\
\hline 2- Keeping the baby swaddled and warm & 9 & 6.3 & 140 & 98.6 & 90.44 & $<0.001^{* *}$ \\
\hline 3- Ensuring the nappy is clean and dry & 24 & 16.9 & 142 & 100.0 & 216.79 & $<0.001^{* *}$ \\
\hline 4- Cuddling and holding the baby & 17 & 12.0 & 142 & 100.0 & 158.67 & $<0.001^{* *}$ \\
\hline 5- Kangaroo care & 25 & 17.6 & 117 & 82.4 & 157.91 & $<0.001^{* *}$ \\
\hline
\end{tabular}


Table 5: Distribution of Nurses' Practices about Symptoms Control, Physiological Monitoring and Nutrition throughout the Program Phases (n=142)

\begin{tabular}{|c|c|c|c|c|c|c|}
\hline \multirow{3}{*}{ Nurses practices } & \multicolumn{4}{|c|}{$\begin{array}{c}\text { Correct practices } \\
(n=142)\end{array}$} & \multirow{3}{*}{$\begin{array}{c}X^{2} \\
\text { P-value }\end{array}$} & \multirow{3}{*}{ P value } \\
\hline & \multicolumn{2}{|c|}{ Pre } & \multicolumn{2}{|c|}{ Post } & & \\
\hline & No & $\%$ & No & $\%$ & & \\
\hline \multicolumn{7}{|l|}{ D-symptoms control: } \\
\hline $\begin{array}{l}\text { a. seizures } \\
1 \text {-give anticonvulsants drug to control seizures as } \\
\text { midazolam or phenobarbitone }\end{array}$ & 10 & 7.0 & 138 & 97.2 & 174.15 & $\underset{* *}{<0.001}$ \\
\hline $\begin{array}{l}\text { b.Reducation of secretion } \\
1 \text {-Perform gentle suctioning and give medications } \\
\text { such as hyocine or glycopyorrlate to decrease } \\
\text { respiratory and salivary secretion }\end{array}$ & 5 & 3.5 & 135 & 95.1 & 286.43 & $\underset{* *}{0.001}$ \\
\hline $\begin{array}{l}2 \text { - Moist swabs or petroleum jelly may be used for } \\
\text { dry mouth lips }\end{array}$ & 4 & 2.8 & 116 & 81.7 & 286.43 & $\underset{* *}{<0.001}$ \\
\hline \multicolumn{7}{|l|}{ E. physiologically monitoring: } \\
\hline $\begin{array}{l}1 \text { - invasive blood pressure monitoring should be } \\
\text { discontinue }\end{array}$ & 4 & 2.8 & 138 & 97.2 & 286.43 & $\underset{* *}{<0.001}$ \\
\hline $\begin{array}{l}2 \text {-Cardiac monitoring should be turned off prior to } \\
\text { disconnecting of mechanical ventilation }\end{array}$ & 9 & 6.3 & 113 & 79.6 & 233.02 & $\underset{* *}{<001}$ \\
\hline 3 -Stop measuring blood tests and blood gas & 18 & $\begin{array}{c}12 . \\
7\end{array}$ & 124 & 87.3 & 122.35 & $\underset{* *}{<0.001}$ \\
\hline $\begin{array}{l}4 \text { - Monitor of physical signs that suggest } \\
\text { discomfort such as crying, tachycardia and } \\
\text { excessive secretion }\end{array}$ & 6 & 4.2 & 128 & 90.1 & 116.07 & $\underset{* *}{<0.001}$ \\
\hline $\begin{array}{l}\text { 5- Perform intermittent physical examination with } \\
\text { auscultations of the heart rate should be continue } \\
\text { after withdrawal life sustaining support }\end{array}$ & 35 & $\begin{array}{c}24 . \\
6\end{array}$ & 107 & 75.4 & 203.80 & $<\underset{* *}{<.001}$ \\
\hline F-Fluid and nutrition: & & & & & & \\
\hline $\begin{array}{l}\text { 1-Continue intravenous hydration and nutrition as } \\
\text { doctor order }\end{array}$ & 6 & 4.2 & 136 & 95.8 & 245.45 & $\underset{* *}{0.001}$ \\
\hline $\begin{array}{l}2 \text { - Reduce volume of enteral feeds in case of } \\
\text { vomiting }\end{array}$ & 0 & .0 & 135 & 95.1 & 63.77 & $\underset{* *}{<0.001}$ \\
\hline 3 -Stop oral nutrition if it lead to discomfort or pain & 8 & 5.6 & 134 & 94.4 & 12.07 & $\underset{* *}{<0.001}$ \\
\hline $\begin{array}{l}4 \text { - Allow neonate to suck if able to do and tolerate } \\
\text { breast feeding }\end{array}$ & 9 & 6.3 & 133 & 93.7 & 260.97 & $\underset{* *}{<0.001}$ \\
\hline 5 -Stop I .V fluid if it could cause distress & 10 & 7.0 & $1 r 2$ & 93.0 & 149.78 & $\underset{* *}{<0.001}$ \\
\hline
\end{tabular}


Table 6: Distribution of Nurses' Practices about Ventilation \& Oxygen Therapy and Family Support throughout the Program Phases (n=142)

\begin{tabular}{|c|c|c|c|c|c|c|}
\hline \multirow{3}{*}{ Nurses practices } & \multicolumn{4}{|c|}{$\begin{array}{c}\text { Correct practices } \\
(n=142)\end{array}$} & \multirow{3}{*}{$\begin{array}{c}X^{2} \\
\text { P-value }\end{array}$} & \multirow[t]{3}{*}{$\begin{array}{l}P \\
\text { value }\end{array}$} \\
\hline & \multicolumn{2}{|c|}{ Pre } & \multicolumn{2}{|c|}{ Post } & & \\
\hline & No & $\%$ & No & $\%$ & & \\
\hline G- ventilation and oxygen therapy & & & & & & \\
\hline $\begin{array}{l}\text { 1-Nurse Turns off the alarms of the ventilator } \\
\text { prior to disconnecting }\end{array}$ & 9 & 6.3 & 132 & 93.0 & 246.63 & $\begin{array}{l}<0.0 \\
01^{* *}\end{array}$ \\
\hline $\begin{array}{l}\text { 2- Nurse performs Suction the endotracheal tube } \\
\text { before removal }\end{array}$ & $v$ & 4.9 & 125 & 90.1 & 246.63 & $\begin{array}{l}<0.0 \\
01^{* *}\end{array}$ \\
\hline $\begin{array}{l}\text { 3- Nurse allows for continuous provision of } \\
\text { supplemental oxygen to provide comfort }\end{array}$ & 10 & 7.0 & 133 & 93.7 & 47.39 & $\begin{array}{l}<0.0 \\
01^{* *}\end{array}$ \\
\hline $\begin{array}{l}\text { 4- Nurse administers morphine if a neonate } \\
\text { exhibits signs of shortness (nasal flaring, air } \\
\text { hunger, colour changes or gasping) }\end{array}$ & 13 & 9.2 & 129 & 90.8 & 213.60 & $\begin{array}{l}<0.0 \\
01^{* *}\end{array}$ \\
\hline I-Family support & & & & & & \\
\hline $\begin{array}{l}\text { 1- Nurse encourages parents to spend more time } \\
\text { with their baby. }\end{array}$ & 18 & 12.7 & 118 & 83.1 & 88.89 & $\begin{array}{l}<0.0 \\
01^{* *}\end{array}$ \\
\hline $\begin{array}{l}\text { 2-Nurse allows to Parents and siblings } \\
\text { opportunities to hold, bath, clothe and feed their } \\
\text { baby }\end{array}$ & 35 & 24.6 & 107 & 75.4 & 203.80 & $\begin{array}{l}<0.0 \\
01^{* *}\end{array}$ \\
\hline $\begin{array}{l}3 \text {-Nurse provides reassurance to parents and } \\
\text { support to overcome their grief. }\end{array}$ & 24 & 16.6 & 124 & 87.3 & 132.15 & $\begin{array}{l}<0.0 \\
01^{* *}\end{array}$ \\
\hline $\begin{array}{l}4 \text {-Nurse help parents to Obtain mementos such } \\
\text { as lock of hair, hand or footprints on a card and } \\
\text { photos of the family together }\end{array}$ & 20 & 14.1 & 100 & 70.4 & 216.79 & $\begin{array}{l}<0.0 \\
01^{* *}\end{array}$ \\
\hline
\end{tabular}


2 Table (7) Total knowledge, practice and Attitude Scores of Nurses Regarding Neonatal Palliative Care throughout the Program Phases (no=142)

\begin{tabular}{|c|c|c|c|c|c|c|}
\hline \multirow[t]{2}{*}{ Topic } & \multicolumn{2}{|c|}{$\begin{array}{l}\text { Pre program } \\
\text { implementation }\end{array}$} & \multicolumn{2}{|c|}{$\begin{array}{l}\text { Post program } \\
\text { implementation }\end{array}$} & \multirow{2}{*}{$\begin{array}{c}\text { Chi } \\
\text { square } \\
\text { Test }\end{array}$} & \multirow[t]{2}{*}{ P value } \\
\hline & No & $\%$ & No & $\%$ & & \\
\hline \multicolumn{5}{|l|}{ Total knowledge score } & \multirow[t]{4}{*}{276.84} & \multirow[t]{4}{*}{$<0.001 * *$} \\
\hline Poor & 125 & $88 . .0$ & 0 & 0.0 & & \\
\hline Fair & 0 & 0.0 & 2 & 1.4 & & \\
\hline Good & 17 & 12.0 & 140 & 98.6 & & \\
\hline \multicolumn{5}{|l|}{ Total practice score } & \multirow[t]{3}{*}{220.34} & \multirow[t]{3}{*}{$<0.001^{* *}$} \\
\hline Incompetent & 136 & 95.8 & 11 & 7.7 & & \\
\hline Competent & 6 & 4.2 & 131 & 92.3 & & \\
\hline \multicolumn{5}{|l|}{ Total attitude score } & \multirow[t]{3}{*}{256.73} & \multirow[t]{3}{*}{$<0.001 * *$} \\
\hline Negative & 138 & 97.2 & 3 & 2.1 & & \\
\hline Positive & 4 & 2.8 & 139 & 97.9 & & \\
\hline
\end{tabular}

Table 8: Correlation between Nurses' Knowledge, Practices and Attitude related to Neonatal Palliative Care and their Personal Characteristics after Program Implementation.

\begin{tabular}{|c|c|c|c|c|c|c|}
\hline & \multicolumn{6}{|c|}{ Pearson correlation coefficient } \\
\hline & \multicolumn{6}{|c|}{ mothers $(n=142)$} \\
\hline & \multicolumn{2}{|c|}{ Knowledge score } & \multicolumn{2}{|c|}{ practices score } & \multicolumn{2}{|c|}{ Attitude score } \\
\hline & Pearson & Sig & Pearson & Sig & Pearson & Sig \\
\hline $\begin{array}{l}\text { Knowledge } \\
\text { score }\end{array}$ & 1 & & $0.657\left({ }^{* *}\right)$ & $<0.001 * *$ & 0.518 & $\begin{array}{c}<0.001 \\
* *\end{array}$ \\
\hline practices score & $0.657\left(^{* *}\right)$ & $<0.001 * *$ & 1 & & .128 & $>0.05$ \\
\hline Attitude score & 0.518 & $<0.001 * *$ & .128 & $>0.05$ & 1 & \\
\hline Age (Years) & -.095 & $>0.05$ & -.073 & $>0.05$ & .081 & $>0.05$ \\
\hline $\begin{array}{c}\text { Years of } \\
\text { experience }\end{array}$ & 0.689 & $<0.001 * *$ & -.061 & $>0.05$ & 0.266 & $0.001 *$ \\
\hline
\end{tabular}

** significant at the 0.01 level (-tailed).

\section{Discussion:}

Neonatal palliative care is a holistic, multidisciplinary care to improve the quality of life of neonates who have a serious or lifethreatening disease ${ }^{(32)}$. In pediatrics, advances in health care mean that many neonates are living longer with these conditions and could benefit from services that focus on quality of life and symptom management. Nurses represent the largest sector of the health care workforce who provides most of the formal palliative care. They provide physical, mental, spiritual care to neonates, symptom management and communicate with the family to satisfy their needs, and help the neonates to achieve a good death ${ }^{(33)}$.

The aim of the current study was to evaluate the effect of educational program 
on nurses' performance regarding neonatal palliative care. This aim was achieved throughout the study findings and the research hypothesis was accepted.

As yielded by the current study findings, the mean age of nurses was $(24.97 \pm 4.807)$ years; this young age could explain the lack of nurses' knowledge in providing palliative care to neonate. Furthermore, the majority of them were dealt with more than 10 children during the period of dying, and nearly three quarters of them didn't take any previous educational programs about neonatal palliative care. These findings are in agreement with a study carried out in Egypt by Moawed (2013) $^{(34)}$ who founded that, the majority of them was dealt with more than 10 children during the period of dying; More than two third of them didn't take any previous educational programs about death, dying or about how to take care of dying children.

On assessing nurses knowledge about neonatal palliative care, the findings of the current study reveals that, the highest percentage of nurses had poor knowledge regarding neonatal palliative care before the implementation of the program. The poor level of nurses knowledge in this study could be associated with the lack of specific palliative care units in Egypt, the fact that palliative care education was not incorporated into either diploma or degree curricula, nurses are overworked because of the nursing shortage in the nursing staff. Therefore, they have limited time to enhance their knowledge about palliative care.

This result is consistent with the studies carried out in Canada, Palestine and Guwahati city by Brazil etal.,(2012) ${ }^{(28)}$; Ayed etal., (2015) (35) ; Sorifa and Mosphea, (2015) (36) found that, the majority of nurses had inadequate knowledge regarding palliative care. After implementation of the program, there was a significant improvement with the number of nurses who achieve a good score in the post period. This finding is matched with the hypothesis number one. The improvement scores indicated that, the program was a successful strategy to increase knowledge and provide information help them to increase their confidence in dealing with the ethical and legal issues they experience.

This study was supported by the study carried out in Seoul, Korea by young-ran, min, and Kyoung-soon (2015) ${ }^{(37)}$ who stated that, the knowledge of nurses in the experimental group was higher than control group after educational program implementation about palliative care. In 
the same line, Joy, (2015) ${ }^{(38)}$; Kim et al. (2011 $^{(39)}$ who conducted a study in United States and Korea, they found that, nurses in the intervention group demonstrated a significant increase of palliative care knowledge.

Findings of the present study reflected that, there was a significant difference in all items of nurses' knowledge pre - post intervention regarding neonatal palliative care. After implementation of the program, all nurses had correct answer regarding definition, benefits and principles of palliative care. This finding supported by the study carried out in Nigeria by Fadare etal., (2014) ${ }^{(40)}$ who founded that, the majority of nurses have good knowledge about the definition of palliative care and recognized the potential benefit of palliative care.

This is proved with the statement from Kennedy (2010) ${ }^{(41)}$ who stated that, nurses should have a positive recognition of palliative care to be able to play the crucial role of a palliative care service provider, especially as a coordinator of hospice care team members in addition to their primary duty of directly taking care of neonates. Also, increasing the recognition of palliative care is important because palliative care is not just about care in the last months or days of a person life but about ensuring quality of life for both neonates and families at every stage of the disease process.

On investigating nurses' practices about palliative care to neonate, the finding of the present study showed that, the majority of nurses had incompetent practices in most areas of neonatal palliative care before program implementation. This finding could be explained by only a few nurses have been trained on palliative care, nurses felt that palliative care is the responsibility of doctors not the nurses, nurses do not feel competent enough to deliver palliative care to the neonate, and lack of hospital policies and human resources. After implementation of the program there was significant improvement with the number of participants who a achieve competent score. These findings match with the hypothesis number two. This is most likely due to the effect of the educational program.

The findings of the current study are supported by the study carried out in Iran by Abaszadeh et al. (2012) $)^{(42)}$ who showed that, continuing education programs resulted in an increase in nurses practice. In this respect, American Academy of Nursing (2010) $)^{(43)}$ recommended training and education to 
enhance the knowledge and skills that nurses bring to the bedside of neonates with life-limiting conditions. Additionally,

\section{Adriaansen and van Achterberg,} (2008) ${ }^{(44)}$ mentioned that, interactive and integrated programs are known to have a positive impact on professional practice as when these programs are offered over a period of weeks, it allows nurses to practice what they are learning and then reflect on their experience.

The present study illustrated that, most of the studied sample believed that, it is not important to discuss with the family about the diagnosis and prognosis of their neonate condition before program implementation. The reason for this might be related with fear of nurses to confront the dying neonates, and probably because they might feel that they are not be competent enough since majority of them didn't take palliative care training and they don't know how to handle the condition. According to Windsor etal., (2008) ${ }^{(45)}$; Tavakol etal., (2008) ${ }^{(46)}$, family have a right to have all information regarding their neonate condition, but this is not so in practice because of the influence of many factors such as culture, religion and patient's peculiarities. After program implementation the present study findings revealed that, the highest percentage of the nurses discussed with the family about their baby diagnosis, prognosis, and treatment.

These findings are corroborated by the study carried out in Nigeria by Fadare etal., (2014) ${ }^{(40)}$ who founded that, the highest percentage of nurses thought that, the family should be informed of their neonate diagnosis and prognosis. In contrary, study done in Addis Ababa, Ethiopia by Kassa etal., (2014) ${ }^{29}$ who founded that, high percentage of nurses hiding the truth about the family and addressed psychological issues.

The Present study illustrated that, the majority of nurses increased confidence in practices skills especially management of pain after program implementation. Similarly, the study carried out in subSaharan Africa by Hansen etal., $\mathbf{( 2 0 0 9}^{(47)}$, who reported that, nurses confidence in pain management improved after intervention program. This is proved with the statement by Harding etal., (2010) $^{(48)}$ who revealed that, education about pain control for health workers is required in order to provide appropriate neonates care. Also, Goldsmith etal., (2008) $^{(49)}$ added that, education about pain control is important because unrelieved pain has a serious effect on the quality of life, interfering with sleep, daily activity, 
enjoyment of life and social interaction . Regarding to nurses attitude after program implementation, it was observed that, the highest percentage of nurses had positive attitude towards neonatal palliative care. These findings match with the hypothesis number three. This could be explained by the education may be the ideal venue to create incremental gains once a high positive attitude is demonstrated. The finding of the current study was similar to a result of a study carried in London by Twamley, etal., (2013) $)^{(50)}$ who founded that, nurses had high level of comfort, confidence, and expressed a more positive attitude to the role of palliative care for neonate. Similarly, Zargham etal., (2011) $^{(51)}$ who carried a study in Iran to examine the effect of palliative education on nurses' attitude and the result showed significant increase in nurses' positive attitude compared to the time before training.

Concerning the responsibility of nurses about drug addiction, Finding of the present study revealed that, the majority of the nurses believed that, drug addiction should be a concern of a nurse when dealing with dying neonates and nearly half of nurses believed to change the subject to something cheerful when a family asks a nurse, "Am my baby dying?" after program implementation. The findings of the current study are in the same line with a study conducted in Addis Ababa, Ethiopia by Kassa etal., (2014) ${ }^{(29)}$ who revealed that, nearly two thirds of the studied nurses believed that, drug addiction should be a concern of a nurse when dealing with dying patients and nearly half of the respondents in the present study believed to change the subject to something cheerful when a patient asks a nurse, “Am I dying?".

The present study revealed that, there is a statistically significant positive correlation between the nurses' knowledge and practice scores. This finding matches with the hypothesis number four. This may be due to the educational program increasing understanding of the palliative care practices and improving links with local services that could make a difference in practice and the utilization of palliative care services. Additionally, more hours of palliative care education help the nurses feel comfortable in providing care to dying neonates and their families. The findings are consistent with findings of Sorifa and Mosphea, (2015) $)^{(36)}$ who indicated that, there is a positive correlation between knowledge and practice scores of palliative care by staff nurses. 
Findings of the present study showed that, there is a statistically significant positive correlation between the nurses' knowledge and attitude scores regarding neonatal palliative care. This could be due to the educational program content, form, and its structures are effective for increasing the nurses knowledge regarding neonatal palliative care that makes positive change in nurses' attitude. This result was disagreed with the finding carried out in Indian by Sujakarkada etal., (2011) ${ }^{(52)}$ who revealed that, there is a negative correlation existed between nurses knowledge and attitude scores toward palliative care.

As shown by the present study, there is a statistically significant positive correlation between the nurses' knowledge about neonatal palliative care and years of experience. This means that, nurses who have more experience with neonatal palliative care services are more likely to have more favorable knowledge. This result is in agreement with the finding by Ayed, (2015) ${ }^{(35)}$ who found that, there is a positive relationship between nurses' knowledge regarding neonatal palliative care and their years of experience.

On investigating the relationship of nurses' attitude and their years of experience, the present study revealed that, there is a statistically significant positive correlation between the nurses' attitude and years of experience. The possible reason for this might be the neonates with life-threatening condition are mostly admitted to the neonatal intensive care unit, thus nurses who worked in this ward had daily contact with those neonates, and may have a powerful coping mechanism and developed favorable attitude towards palliative care. Also, the more exposure to death, the more awareness of ones own emotions. The present study are in accordance with the study carried out in Jordan by Khader, (2010) ${ }^{(53)}$; Abu Hasheesh etal., (2013) ${ }^{(54)}$ who found a positive correlation between nurses attitude and years of experience in caring of dying.

\section{Conclusion:}

Based on the results of the present study, it can be concluded that, the research hypothesis is accepted while it was found that, the educational program are an effective method to improve the nurses' knowledge, practice, and attitude regarding neonatal palliative care. However, There is a statistically significant positive correlation between nurses' knowledge, practice and attitude related to neonatal palliative care and their 
personal characteristics after program implementation.

\section{Recommendations:}

In the light of the findings of the current research, the following recommendations are suggested:

1. Continuous refreshing training program should be provided in order to update the nurses' knowledge, improve their level of practice and develop a positive attitude towards neonatal palliative care.

2. Neonatal palliative care must be incorporated in undergraduate nursing education curricula.

3 Availability and accessibility of written guidelines in hospitals and units related to neonatal palliative care.

4.Palliative care home visits should be arranged as a part of student curriculum to provide first - hand experience.

5. Nurse administrator must render attention in developing and maintaining neonatal palliative care.

6. Further researches can be done in other clinical setting regarding methods to improve the quality of neonatal palliative care.

\section{References:}

1. World Health Organization. Effective palliative care for children2013.
Available from: www.who.int/cancer /palliative/en/.

2. Lathrop A, Vande-Vusse L. Affirming motherhood: validation and invalidation in women's perinatal hospice narratives. Birth 2011; 38: 256-65.

3. Friebert S. NHPCO facts and figures: pediatric palliative and hospice care in America. Alexandria, VA: National Hospice and Palliative Care Organization. 2009

4. World health organization. Global atlas of palliative care at end of life. World Health Organization. Worldwide Palliative Care Alliance 2014. Retrieved from:

www.who.int/nmh/global_Atlas_of_palli ative care.

5. Crozier F, Hancock LE. (2012): Pediatric palliative care: beyond the end of life. Pediatric Nursing. 2012; 38(4): 198-227.

6. World Health Organization. WHO definition of palliative care 2010. Retrieved from: http://www.who.int/cancer/palliative/ definition/en.

7. Ewing B. Wish fulfillment: palliative care and end-of-life intervention. Pediatric Nursing; 2009; 35(2): 81-85.

8. Angelini DJ. Interdisciplinary and interprofessional education: what are the key issues and considerations for the 
future? Journal of Perinatal \& Neonatal Nursing;2011; 25: 175-179.

\section{Hinds PS, Oakes LL, Hicks J, Powell B,} Srivastava DK, Baker JN, Furman WL. Parent-clinician communication intervention during end-of-life decision making for children with incurable cancer. Journal of Palliative Medicine 2012; 15(1): 916-922.

10. Foster TL, Lafond DA, Reggio C, Hinds PS. Pediatric palliative care in childhood cancer nursing: from diagnosis to cure or end of life. Seminars in Oncology Nursing;2010;26: 205-221.

11. Xu J, Kochanek KD, Tejada-Vera B. (2009): Deaths: preliminary data for 2007. National Vital Statistics Report; 2009;58(1): 1-51Avalible from: http://www.cdc.gov/nchs/products/nvsr.htm.

12.Aladangady N, de Rooy L. Withholding and withdrawal of life sustaining treatment for newborn infants. Early Human Development;2012; 88(2): 65-69.

13. Mancini A, Uthaya S, Beardsley C, Wood D, Modi N. Practical guidance for the management of palliative care on neonatal units. Royal Collegue of Peadiatrics and Children Health. Chelsea and Westminster Hospital. Retrieved from 2014 www.chelwest. nhs.uk/services/childrens-services/ neonatal-services/links/Practicalguidance-for-the-management-of-
palliative-care-on-neonatal-units-Feb2014.pdf.

14. Refaat O. Population stabilization policies and programs in Egypt 2014;.18.

15. Center to Advance Palliative Care. Improving palliative care in nursing homes. New York: Center to Advance Palliative Care. New York: Author 2008.

16. Goebel JR, Sherbourne CD, Asch SM, Meredith L, Cohen AB, Hagenmaier E, Lorenz KA. (2013): Addressing patients' concerns about pain management and addiction risks. Pain Management Nursing;2009; 11(2): 92-98.

17. Feudtner C, Kang TI, Hexem K. (2011): Pediatric palliative care patients: a prospective multicenter cohort study. Pediatrics 2011;127(6): 1094-1101.

18. Skår R. Knowledge use in nursing practice: the importance of practical understanding and personal involvement. Nurse Educ Today 2010; 30: $132-6$.

19. Onyeka TC, Velijanashvili M, Abdissa SG, Manase FA,Kordzaia D. Twenty first century palliative care: a tale of four nations. Eur $\mathrm{J}$ Cancer Care (Engl)2013; 22: 597-604.

20. International Council of Nurses. Nurses' role in providing care to dying 
patients and their families [Position statement]. Retrieved from 2012 www.icn.ch/images/stories/documents/ publications/position_statements/A12_

Nurses_Role_Care_Dying_Patients.

21. Unroe KT, Meier DE. Palliative care and hospice: opportunities to improve care for the sickest patients. The Notre Dame Journal of Law, Ethics and Public Policy; 2011;25(2): 413-426.

22. Kain V, Gardner G, Yates P. (2009): Neonatal palliative care attitude scale: development of an instrument to measure the barriers to and facilitators of palliative care in neonatal nursing. Pediatrics 2009; 123(2): 207-213.

\section{Prevost S, Rushton CH, Chrastek J,}

Kirshling J. Palliative and end-of life are: transformational models of nursing across settings. In Institute of Medicine, the future of nursing: leading change, advancing health; 2010; G21-G28).

24. Institute of Medicine. The future of nursing: leading change, Advancing Health2010. Retrieved from: http://www.iom.edu/Reports/2010/Thefuture-of-nursing-leadingchangeadvancing- health.aspx.

25. Al Qadire M. Nurses' knowledge about palliative care: a cross-sectional survey. Journal of Hospice \& Palliative Nursing 2014; 16(1): 23-30. doi:10.1097/NJH .0000000000000017 .
26. Kim S, Hwang WJ. Palliative care for those with heart failure: nurses' knowledge, attitude, and preparedness to practice. European Journal of Cardiovascular Nursing; 2014;13(2): 124-133. doi: 10.1177/1474515 113519521.

27. Pitman S. Evaluating a self-directed palliative care learning package for rural aged care workers: a pilot study. International Journal of Palliative Nursing 2013; 19(6): 290-294.

28. Brazil K, Brink P, Kaasalainen S, Kelly ML, McAiney C. Knowledge and perceived competence among nurses caring for the dying in longterm care homes. International Journal of Palliative Nursing 2012; 18(2): 77-83.

29. Kassa H, Murugan R, Zewdu F, Hailu M, and Woldeyohanness D.Assessment of knowledge, attitude and practice and associated factors towards palliative care among nurses working in selected hospitals, Addis Ababa, Ethiopia. BMC Palliative Care 2014; 13:6. Available at: doi: 10.1186/1472-684X-13-6.

30. South Central Palliative Care Group. South central neonatal network guideline 2012. Retrieved from: http://www.southcentral.nhs.uk /what-we-are-doing/end-of-life- 
care/dnacpr-acp- documents/?.

31. Frommelt KH. Attitudes toward care of the terminally ill: an educational intervention. American Journal of Hospice and Palliative Care 2003; 20(1): 13-22.

32. The National Cancer Institute. Palliative care in cancer. Beth esda 2014Availablefrom:http://www.cancer .gov/cancertopics/factsheet/Support/pa lliative-care.

33. Ellington L, Reblin M, Clayton MF, Berry P, Mooney K. Hospice nurse communication with patients with cancer and their family caregivers. Journal of Palliative Medicine2012; 15(3): 262-268. Retrieved from: http://dx.doi.org/10.1089/jpm.2011.0287.

34. Moawed G. Nurses' perception of obstacles and supportive behaviors in providing end of life care to critically ill pediatric patients. Journal of Biology, Agriculture and Healthcare.2013; 3(2).

35. Ayad A, Sayej S, Harazneh L, Fashafsheh I, Eqtait F. The nurses knowledge and attitudes towards the palliative care. Journal of Education and Practice 2015; 6(5): 91-99.

36. Sorifa B, Mosphea K. Knowledge and practice of staff Nurses on Palliative Care, IJHRMLP 2015; 1(2).

\section{Young-ran Y, min K, Kyoung-Soon}

L. Development and evaluation of an education program for professional palliative care nursing. Journal Academic Nursing 2015; 45(1): 139145.

38. Joy YL. The influence of a palliative care education intervention in increasing knowledge and selfefficacy of nurses practicing in longterm care, Unpublished Doctoral Dissertation, University of Connecticut Graduate school.2015

39. Kim HS, Kim BH, Yu SJ, Kim S, Park SH, Choi S, Jung Y. The effect of an end-of-life nursing education consortium course on nurses' knowledge of hospice and palliative care in Korea. Journal of Hospice \& Palliative Nursing 2011; 13(4): 222-9. doi:10.1097/NJH.0b013e318210fdec.

40. Fadare JO, Obimakinde AM, Olaogun DO, Afolayan JM, Olatunya O, Ogundipe KO. Perception of nurses about palliative care: experience from South-west Nigeria, Annals of Medical and Health Sciences Research 2014; 4(5): 723-727.

Available

at: http://www.amhsr.org.

41. Kennedy J. Demystifying the role of nurse practitioners in hospice: nurse 
practitioners as an integral part of the hospice plan of care. Home Healthcare Nurse; 201230(1): 48-51. Retrieved from: http://dx.doi.org /10.1097/NHH.0b013e31823aa87f.

42. Abbaszadeh A, Sabeghi H, Heidary A, Borhani F. Assessment of the effect of continuing education program on nurse's knowledge, attitude and performance about documentation. Evid Based Care 2012; 275-83.

43. American Academy of Nursing. In Tilden V., Corless I, Dahlin C, Ferrell B, Gibson R, Lentz J.(Eds.), American Academy of Nursing Policy Brief: Advance Care Planning as an Urgent Public Health Concern. Washington, DC.2010

44. Adriaansen, MJM, van Achterberg T. The content and effects of palliative care courses for nurses: a literature review. International Journal of Nursing Studies 2008; 45: 471$485 . \quad$ doi:10.1016/j.ijnurstu. 2007.01.016.

45. Windsor JA, Rossaak JI, Chaung D, Ng A, Bissett IP, Johnson MH. Telling the truth to Asian patients in the hospital setting. N Z Med J 2008; 121: 929 .
46. Tavakol M, Murphy R, Torabi S. Educating doctors about breaking bad news: an Iranian perspective. J Cancer Educ 2008; 23(1): 260-3.

47. Hansen L, Goodell TT, Dehaven J, Smith M. (2009): Nurses' perceptions of end of life care after multiple interventions for improvement. Am J Crit Care 2009; 18: 26371.

48. Harding R, Powell RA, Kiyange F, Downing $J$, Mwangi-Powell $F$. Provision of pain- and symptomrelieving drugs for HIV/AIDS in subSaharan Africa. J Pain Symptom Management 2010; 40(3): 405-415.

49. Goldsmith B, Dietrich J, Du Q, Morrison RS . Variability in access to hospital palliative care in the United States. J Palliat Med 2008; 11(8): 3267-3274.

50. Twamley K, Kelly P, Moss R, Mancini A, Craig F, Koh M, Polonsky R, Bluebond-Langer $M$. Palliative care education in neonatal units: impact on knowledge and attitudes. BMJ Supporative \& Palliative Care 2012. doi: 10.1136/bmjspcare.

51. Zargham-Boroujeni A, Bagheri SHS, Kalantari M, Talakoob S, Samooai F. Effect of end-of-life care 
education on the attitudes of nurses in infants' and children's wards. Iran J Nurs Midwifery Res 2011; 16(1): 9399.

52. SujaKarkada, Nayak BS, Malathi. Awareness of palliative care among diploma nursing students. Indian $\mathbf{J}$ Palliat Care 2011; 17(1): 20- 23.

53. Khader K. The effectiveness of an educational program on Jordanian nurses' attitudes toward caring for dying patients. Unpublished Doctoral Dissertation. The University of Jordan, Amman, Jordan 2010.

54. Abu Hasheesh MO, Abozeid SA, ElSaid SG, Alhujaili AD. Nurses characteristics and their attitude toward death and caring for dying patients in Jordan. Health Science journal 2013; 7(4): 338. 